\title{
Memupuk Jiwa Pustakawan Sejak Dini: Refleksi Implementasi Literasi Informasi dalam Menciptakan Masyarakat Terinformasi
}

\author{
Umar Falahul Alam* \\ Universitas Islam Negeri Walisongo Semarang, Jl. Prof Dr. Hamka, Kampus 3, Ngaliyan, Semarang, Indonesia
}

Introduction. information literacy for all of the community is a condition that is predicted
by the Indonesian government to be realized immediately. This achievement will create
an informed society. This situation can be realized if the librarian's soul becomes the soul
of the community. Therefore, two things that must be prepared are first, increasing
interest in reading in the community, and second, carrying out an information literacy
program.

\section{Pendahuluan}

Istilah jiwa pustakawan merupakan istilah yang merujuk pada "ghiroh" pustakawan sebagai pihak yang dianggap responsif terhadap dinamika perkembangan informasi dan ilmu pengetahuan. Responsif dalam arti selalu melakukan update informasi yang berkembang secara berkesinambungan, dan menyebarkan informasi terbaru itu ke masyarakat penggunanya. Dua kegiatan ini yang menjadi landasan kegiatan pokok, fungsi dan tugasnya, sehingga masyarakat sebagai klien yang dilayaninya dapat menjadi masyarakat yang berpribadi sebagai "informed society". Banyak pustakawan sampai saat ini, diyakini belum begitu peduli dengan jiwa pustakawan seperti ini. Banyak pustakawan yang melakukan kegiatan kepustakawannanya hanya sekedar meruntuhkan kewajibannya sebagai pustakawan dan hanya sekedar menjalankan tugasnya saja, seperti melakukan kegiatan-kegiatan harian (housekeeping). Berapa banyak pustakawan yang selalu menyempatkan diri setiap hari untuk menyisakan di jam-jam sibuknya, untuk

\footnotetext{
* Corresponding author.

Email address: valahulalam@walisongo.ac.id (U. F. Alam)
} 
menggali informasi terbaru, mengolah dan menyebarkan informasinya kepada pemustakanya? Berapa banyak pustakawan yang masih bisa menyisakan waktunya untuk membaca konten dari buku-buku yang "inspired", mengupasnya, melakukan sintesa karenanya, lalu menyebarkannya kepada pemustaka? Berapa banyak pustakawan yang menyempatkan untuk menuliskan dalam format apapun untuk memberikan kemelekan informasi kepada pemustakanya? Berapa banyak pustakawan yang memiliki jiwa seperti ini? Padahal jiwa pustakawan seperti yang dimaksudkan di atas, merupakan pintu menuju akses informasi seluas-luasnya. jiwa seperti jiwa pustakawan "yang sebenarnya" ini seharusnya mulai dipupuk dalam keseharian masyarakat sejak seseorang mulai diajarkan mencintai untuk gemar membaca, berhitung, dan belajar banyak hal, slogan pemerintah untuk merealisasikan semangat "Literation for alf' pasti akan segera tercapai

\section{Tinjauan Pustaka}

\subsection{Pustakawan dan Gerbang Pengetahuan}

Sebagai salah satu profesi, pustakawan dengan berbagai dinamikanya sudah mulai familiar di telinga masyarakat Indonesia. Dari yang awalnya masih malu-malu berterus terang, hingga maraknya ajang lomba pustakawan berprestasi dari berbagai kelembagaan, menjadikan pamor pustakawan mulai naik daun dan cukup dihormati. Banyaknya taman baca, pojok baca di daerah-daerah, di pelosok-pelosok desa, ditambah dengan masifnya layanan yang banyak melibatkan peran serta masyarakat dari perpustakaan-perpustakaan berplat merah turut mendongkrak peran pustakawan dalam berbagai kegiatan layanan informasinya, semakin memastikan posisi pustakawan aman bertengger di benak masyarakat luas.

Label pustakawan sebagai manifestasi dari kompetensinya juga menjadi beragam, dari pustakawan tradisional, pustakawan campuran (blended librarian), pustakawan profesional, dan dalam ranah yang lebih sempit lagi terdapat pustakawan spesialis subyek, game pustakawan, pustakawan peneliti, guru pustakawan, pustakawan pemikir, bahkan pustakawan birokrat, pustakawan kutu loncat dan lain sebagainya. Sehingga dengan demikian kiprah dan peran pustakawan sebagai mitra bagi klien yang dilayani menjadi sangat berarti. Apapun sematan pustakawan yang hadir pada diri setiap pustakawan, pada dasarnya pustakawan sejak beberapa dekade yang lalu, digadang-gadang sebagai profesi yang memiliki ikatan yang sangat kuat (urwatul wutsqa) dengan gerbang ilmu pengetahuan. Pustakawan harus mampu menjadi 'guardian of knowledge' (gerbang pengetahuan) dalam hal pengembangan informasi, berperan dalam "agent of change" dalam bidang pembangunan masyarakat (Wahyuni, 2019). Maka apapun sematan pustakawan tersebut di atas, inti dari entitas pustakawan salah satunya adalah mendorong terbentuknya masyarakat menjadi komunitas yang menjadikan membaca sebagai salah satu pendorong untuk belajar sepanjang hayat di semua level media, baik melalui jalur pendidikan formal, keluarga, tempat ibadah, maupun pusat-pusat kegiatan lainnya (Lasa $\mathrm{H}$ and Suciati, 2017).

\subsection{Kode Etik Pustakawan}

Sebagai sebuah profesi yang "profesional”, kode etik pustakawan perlu disediakan untuk memberikan jalan lurus terhadap segala kinerja pustakawan di mana pustakawan bekerja dan mengembangkan karirnya. Jalan lurus ini mengatur rel kegiatan pustakawan dari berbagai sisi, termasuk tingkah laku, etika, komunikasi dan kerjasama dengan 
berbagai pihak, layanan-layanan yang diberikan, hingga mengatur pelanggaran dan hukuman. Fungsi kode etik ini dengan demikian sebagai media pengawasan/kontrol terhadap sepak terjang pustakawan, agar tercipta suasana harmonis, terkendali, baiknya citra/image masyarakat, nyaman, dan menyejukkan bagi semua pihak.

Di bagian mukadimah dari naskah kode etik pustakawan yang berkaitan dengan tema penulisan ini dapat dinukilkan sebagai berikut" di alam keterbukaan informasi, perlu ada kebebasan intelektual dan memperluas akses informasi bagi kepentingan masyarakat luas. Pustakawan ikut melaksanakan kelancaran arus informasi dan pemikiran yang bertanggung jawab bagi keperluan generasi sekarang dan yang akan datang. Pustakawan berperan aktif melakukan tugas sebagai pembawa perubahan dan meningkatkan kecerdasan masyarakat untuk mengantisipasi perkembangan dan perubahan di masa datang (Hermawan and Zen, 2010).

\subsection{Literasi Informasi}

Literasi informasi diyakini sebagai sebuah kemampuan seseorang dalam melakukan pengelolaan informasi yang dibutuhkan dan juga dimanfaatkan. Kemampuan ini membutuhkan kecakapan dalam memastikan kebutuhan mendasar dari informasi yang dicarinya, hingga sampai pada kecakapan melakukan sintesa terhadap informasi itu, sehingga menimbulkan informasi baru setelah dikelola. Modal utama dalam kemampuan ini adalah kesadaran pentingnya membaca, menyimak, memahami, mendalami dan membuat review/penilaian. Kemampuan ini sangat vital, dikarenakan tidak dimilikinya kapabilitas dalam literasi informasi ini, bisa menyebabkan seseorang menjadi tidak melakukan pembelajaran apa-apa, dan hanya akan menjadikannya jumud dan tidak bergerak sama sekali (Falahul Alam, 2016).

Kemampuan literasi informasi yang dimiliki seseorang jika dihubungkan dengan masyarakat luas, akan menghasilkan hubungan sebab akibat yang saling mempengaruhi. Masyarakat terinformasi seperti yang didefinisikan Webster, merupakan tipologi masyarakat ideal di era informasi yang memiliki kepedulian secara personal maupun sosial dalam mencipta, mengolah, mengakses, dan memanfaatkan informasi (Dewi, 2015). Setidaknya jika kemampuan literasi informasi hanya dimiliki sebagian kecil dari jumlah masyarakat, terbentuknya masyarakat terinformasi masih jauh dari impian.

\section{Metodologi}

Metode penelitian dalam penulisan ini menggunakan penelitian kepustakaan. Analisis menggunakan teknik deskriptif dikembangkan berdasarkan pada sejumlah literatur yang memiliki relevansi dengan topik penelitian, dengan meng-capture (memotret) realitas rata-rata yang terjadi di masyarakat, sehingga mampu menimbulkan sintesa atas jiwa pustakawan seperti apa yang harus ditanamkan (hadir) pada setiap generasi anak bangsa.

\section{Pembahasan}

\subsection{Karakteristik Pustakawan dan Semangat Menumbuhkan Literasi Informasi}

Beberapa karakteristik jiwa pustakawan yang berkaitan dengan semangat berbagi informasi dan mempengaruhi tingkat literasi di masyarakat, setidaknya dapat dibagi menjadi 3 (tiga) katagori: 
a. Pertama, pustakawan yang sadar betul atas pentingnya konsep literasi informasi dan menerapkan dengan sungguh-sungguh dalam kinerja profesi pustakawannya.

b. Kedua, pustakawan yang menyadari pentingnya konsep literasi informasi namun memiliki resistensi dalam penerapannya, dikarenakan munculnya kendala secara teknis maupun kemampuan akademis,

c. Ketiga, pustakawan yang tidak begitu peduli dengan konsep literasi informasi, dan tidak peduli dengan penerapannya di lingkungan kerjanya, disebabkan masih banyak kegiatan atau pekerjaan pustakawan yang harus dikerjakan.

Tiga karakteristik jiwa pustakawan di atas sangat mempengaruhi dinamika perkembangan kemampuan literasi informasi di berbagai kalangan pemustaka. Menelisik terhadap eksistensi pustakawan yang peduli dengan konsep literasi informasi dan penerapannya di masyarakat, pustakawan perguruan tinggi merupakan pustakawan yang paling berperan dalam menuntaskan kekurangan kemampuan pemustaka dalam meningkatkan kemampuan literasi informasi, meskipun jenis perpustakaan lain seperti perpustakaan daerah di bawah Perpustakaan Nasional dan perpustakaan sekolah sangat memiliki peranan yang sangat besar berhadapan dengan persoalan minat baca di masyarakat dan anak didik.

Pustakawan-pustakawan perguruan tinggi memang cukup intensif menyelenggarakan kegiatan-kegiatan berhubungan dengan literasi informasi ini, seperti dalam kegiatan pendidikan pemakai, pelatihan ORS (Online Research Skills), pelatihan-pelatihan mengenai gaya selingkung penulisan ilmiah, pelatihan manajemen referensi, hingga pendampingan terhadap aktifitas "term of paper" (bimbingan penulisan karya tulis ilmiah). Sedangkan pustakawan-pustakawan yang tersebar di berbagai perpustakaan daerah dan perpustakaan sekolah, juga melakukan pendekatan-pendekatan persuasif dan lempar bola ke klien pemustakanya dengan melakukan berbagai kegiatan membaca, lewat program kegiatan literasi sekolah misalnya, yang mewajibkan 3 (tiga) kegiatan utama, yaitu pembiasaan membaca, Pengembangan literasi, dan pembelajaran dengan tugas menulis. Pembiasaan membaca dilakukan dengan kewajiban setiap siswa untuk membaca selama 15 menit terhadap buku non-pelajaran sebelum pelajaran dimulai. Tahapan pengembangan dilakukan dengan meningkatkan budaya literasi melalui kegiatan Jumat Bahasa. Dan tahap pembelajaran dilakukan dengan melakukan eksplorasi terhadap bahan bacaan (pengayaan) pelajaran Bahasa Indonesia yang disertai tugas menulis (Imanugroho and Ganggi, 2018).

Kedua kegiatan pustakawan di atas, meskipun berbeda tingkat pemustaka yang dilayaninya, beda materi, dan juga beda penanganannya, namun keduanya memiliki keterhubungan yang berkelindan untuk meningkatkan budaya membaca, menyitir, melakukan sintesa, mengembangkan nalar kritis, bahkan mencipta informasi baru yang diyakini menjadi landasan dasar dalam penciptaan masyarakat yang terinformasi. Ironisnya adalah, pustakawan yang getol menyebarkan, membuat pelayanan dan merancang kegiatan literasi informasi ini tidak begitu banyak, dan kurang serius untuk melangsungkan kegiatan literasi informasi yang berkelanjutan. Persoalan ini tentu saja akan membuat perancangan untuk menciptakan masyarakat luas yang memiliki keberaksaraan informasi, akan berjalan sangat lambat, untuk menghindari istilah hanya jalan di tempat. Perpustakaan Nasional RI memang mensinyalir tercatat kurang lebih 16.331(enam belas ribu tigaratus tiga puluh satu) pegiat literasi yang tersebar hingga ke pelosok desa di Nusantara, yang dilakukan melalui media baca kuda pustaka, becak pustaka, motor pustaka, dan lainnya (Perpusnas RI, 2021), namun menurut penulis yang disebutkan tersebut hanya merupakan pojok-pojok atau taman-taman baca, yang kurang menyentuh pada aspek usaha untuk meningkatkan kemampuan literasi informasi masyarakat secara personal. Taman-taman baca hanya berusaha untuk menyediakan 
bacaan-bacaan terhadap masyarakat, yang pengelolaan koleksi tidak begitu diperhatikan, dan pengelolaan taman baca dilakukan hanya sambil lalu.

\subsection{Literasi Informasi dan Masyarakat Terinformasi}

Literasi informasi dan masyarakat yang terinformasi merupakan rangkaian grafik menuju kondisi terbentuknya kemakmuran informasi di masyarakat luas. Gaung gerakan masyarakat informasi sudah lama dilakukan lewat berbagai macam usaha dan kegiatankegiatan strategis. Salah satunya adalah dengan adanya kegiatan konferensi WSIS ( World Summit of Information Society), sebuah konferensi tingkat dunia yang menginisiasi pembentukan masyarakat yang terinformasi, pada setiap degup jantung dan gerak kreatifitas hariannya. Setidaknya kegiatan konferensi ini telah dilaksanakan beberapa kali diantaranya pada tahun 2003 di Genewa, 2005 di Tunisia, dan terakhir dilaksanakan bulan Mei 2021 secara daring dengan tema "ICTs for Inclusive, Resilient and Sustainable Societies and Economies (WSIS Action Lines for achieving the Sustainable Development Goals)" (Kominfo, 2021).

Masyarakat informasi menurut William Martin, adalah sebuah tatanan kehidupan masyarakat yang selalu menggantungkan aktifitas dan pola hidup dengan cara memanfaatkan teknologi informasi dan komunikasi untuk mengakses kebutuhan informasi dari berbagai sumber yang terpercaya (Rodin, 2013). Tatanan ini setidaknya akan tergantung pada kemampuan masyarakat dalam memahami penerapan Langkahlangkah beberapa model literasi informasi. Masyarakat seperti ini, meminjam istilah Pendit merupakan masyarakat modern yang selalu mengandalkan berbagai teknologi teks, untuk memajukan peradaban bagi dirinya sendiri berbasis pada ilmu yang dimiliki dan teknologi yang menyertainya (Delviatma, 2015). Masyarakat modern ini akan memahami kebutuhan informasi, mengetahui informasi yang dibutuhkan ada dimana, mengerti cara untuk mendapatkan informasi, dan mampu memanfaatkan informasi yang ditemukan untuk keperluan memastikan keputusan seperti apa yang akan diambil. Dengan demikian, setiap orang dalam masyarakat itu dapat bertindak berdasarkan sumber-sumber informasi yang telah dicerna terlebih dahulu, sehingga setiap keputusannya tidak hanya disebabkan karena mengikuti tindakan orang lain. Seperti Inilah manusia yang beradab dan berpikir kritis, yang akan eksis dalam derap abad informasi.

\subsection{Meningkatkan Minat Baca Masyarakat}

Kegiatan membaca diyakini menjadi media transfer informasi dan pengetahuan yang paling dominan, semakin banyak membaca semakin banyak pula informasi yang diperoleh. Semakin sedikit membaca, semakin miskin informasinya. Bila dibuat perbandingan antara seseorang yang gemar membaca dan yang jarang membaca, perbandingan yang logis yang bisa digambarkan adalah adanya ekspresi orang yang gemar membaca lebih percaya diri, memiliki pengetahuan yang lebih tercerahkan, dan juga lebih memiliki artikulasi dalam menyampaikan pesan. Gemar membaca tumbuh dan berkembang sejalan dengan adanya stimulan yang ada pada masing-masing individu. Stimulan tersebut bisa datang dari arah manapun, bisa tumbuh dari dalam dirinya sendiri, dari lingkungan keluarga dan lingkungan, dari dorongan-dorongan eksternal lainnya. Digalakkannya kebiasaan dan kegemaran membaca terlihat dilakukan oleh berbagai lembaga seperti perpustakaan daerah, perpustakaan desa, atau perpustakaan sekolah. Perpustakaan keliling, adanya mobil pintar, dan diselenggarakannya banyak taman-taman 
pintar bertujuan agar kegemaran membaca bisa mulai diminati dan dimulai oleh masyarakat tidak hanya untuk anak-anak usia dini, melainkan untuk masyarakat dari berbagai usia. Para Ibu rumah tangga bisa mulai mengembangkan kegemaran memasak dengan meningkatkan kegemarannya dengan membaca buku-buku tentang masakan. Para petani, lebih tercerahkan teknik dan metode bercocok tanam dengan membaca tentang bercocok tanam dan berladang. Para nelayan meningkatkan pengolahan hasil tangkapan ikan di lautan dengan membaca tentang budidaya kelautan dan sebagainya. Memang hal ini menjadi tantangan yang cukup besar disebabkan karena minat membaca di masyarakat yang masih rendah (Mustangin, 2018).

\subsection{Jiwa Pustakawan yang Tumbuh di Masyarakat}

Jumlah populasi masyarakat yang terus berkembang memberi konsekwensi akan meningkatnya kebutuhan informasi bagi masyarakat. Kebutuhan informasi tersebut bisa diperoleh melewati beberapa media seperti buku, majalah, koran, atau media elektronik, sebutlah umpamanya televisi, atau informasi yang dapat diperoleh lewat gaget, atau HP nya masing-masing. Masifnya informasi yang dibutuhkan masyarakat, menjadi tanggung jawab banyak pihak, termasuk pemerintah dan kelompok masyarakat yang berkhidmat terhadap diseminasi informasi yang harus selalu" terbuka" seiring munculnya semangat keterbukaan informasi publik yang telah memperoleh legitimasinya di Indonesia ini. Kendala yang paling umum muncul di permukaan adalah skill (keterampilan) literasi informasi masyarakat yang belum merata, juga perilaku masyarakat terhadap teknik akses informasi yang diyakini dilakukan oleh sebagian besar masyarakat tanpa mempertimbangkan kualitas, otoritas sumber-sumber informasi. Kenyataan ini tentunya harus mendapatkan perhatian oleh pemerintah dan kelompok masyarakat yang intensif mengabdikan dirinya dalam bidang komunikasi dan informasi, salah satu dari Sebagian elemen kelompok tersebut adalah pustakawan. Tantangan terhadap persoalan ini, sebenarnya sudah gamblang dan terlihat jelas sebagai potret buram terhadap kualitas literasi informasi masyarakat di negeri ini, dan memperoleh perhatian yang serius oleh pemerintah dan sebagian pustakawan yang tersebar di berbagai wilayah.

Jiwa pustakawan yang tercermin dalam kode etik pustakawan, serta tugas-tugas dan kewajiban di dalam kegiatan menyeluruh sebagai fungsional pustakawan, dapat dianggap sebagai dasar-dasar kegiatan seorang pustakawan yang bertanggung jawab terhadap profesinya. Sebagai penjabaran terhadap profesinya tersebut seorang pustakawan harus mengabdikan jiwa raganya agar arah yang terdapat dalam kode etik dan fungsional tersebut tidak bergeser dan tetap menjadi pedoman. Dengan demikian seorang pustakawan harus memfungsikan dirinya menjadi pelaku yang ikut bertanggungjawab atas kemelekan informasi di masyarakat. Fungsi ini tentunya harus dilakukan dengan kerja nyata dalam memastikan elemen-elemen masyarakat menjadi "literate persor".

Interaksi pustakawan dan masyarakat, lewat sebuah media kegiatan-kegiatan yang berupaya memberikan keterampilan membaca, memahami informasi, menganalisa informasi, memanfaatkan informasi, dan menyebarkan informasi yang diperoleh dari hasil sintesa tersebut, perlu dibarengi dengan kemampuan memilih informasi yang relevan dan teknik terhadap akses sumber informasi yang bermartabat. Masifnya interaksi ini, semakin lama akan menimbulkan penciptaan dalam diri masyarakat akan tugas dan tanggung jawab pustakawan secara fungsional tersebut, sehingga muncul entitas pustakawan baru dalam setiap sanubari masyarakat. Disinilah jiwa pustakawan masyarakat akan berperan secara dinamis dalam sepak terjang masyarakat banyak dalam mengelola kebutuhan informasi masyarakat secara mandiri. Dengan demikian, jika keadaan ini dapat terbentuk, masyarakat terinformasi yang digadang-gadang sebagai 
bentuk kemakmuran informasi bersama akan menjadikan masyarakat menjadi komunitas yang mencerahkan satu dengan lainnya.

\section{Kesimpulan}

Jiwa pustakawan yang ringan tangan membantu, memperjuangkan, dan berdedikasi memberikan layanan literasi informasi kepada pemustakanya harus dimiliki oleh segenap lapisan masyarakat, dengan merealisasikan kegiatan-kegiatan penciptaan literasi informasi terhadap berbagai kegiatan bermasyarakat. Masyarakat yang gemar membaca, menelusur informasi-informasi yang dibutuhkan, memecahkan berbagai persoalan dalam membuat keputusan berdasarkan ilmu dan informasi yang diolah sebelumnya, akan menjadikan kehidupan masyarakat ditopang oleh pengetahuan yang baik dan bisa dipertanggungjawabkan. Masyarakat yang mengaplikasikan derap Langkah hidupnya seperti ini, akan menciptakan masyarakat yang terinformasi, yang memiliki kemakmuran informasi secara kolegial.

\section{Daftar Pustaka}

Delviatma, Riva. "Kebiasaan Berbagi Informasi: Masyarakat Lisan Dan Masyarakat Budaya-Tulis." Integrasi Pustakawan Menuju Masyarakat Informasi: Suatu Perspektif Sosial-Budaya, edited by Ike Iswary Lawanda, 1st ed., Sagung Seto, 2015, pp. 95-116.

Dewi, Amalia Nurma. "Kemiskinan Informasi Pada Komunitas X.” Integrasi Pustakawan Menuju Masyarakat Informasi: Suatu Perspektif Sosial-Budaya, edited by Ike Iswary Lawanda, 1st ed., Sagung Seto, 2015, pp. 127-44.

Falahul Alam, Umar, and Kemampuan Literasi Informasi. Kemampuan Literasi Informasi Mahasiswa Dan Peranan Perpustakaan Dalam Proses Belajar Mengajar Di Perguruan Tinggi. pp. 92-105, http://download.portalgaruda.org/article.php?article=441372\&val=7255\&title=Ke mampuan Literasi Informasi Mahasiswa dan Peranan Perpustakaan Dalam Proses Belajar Mengajar di Perguruan Tinggi.

Hermawan, Rachman, and Zulfikar Zen. Etika Kepustakawanan: Suatu Pendekatan Terhadap Kode Etik Pustakawan Indonesia. 1st ed., Sagung Seto, 2010.

Imanugroho, Satrio, and Roro Isyawati Permata Ganggi. "Program Gerakan Literasi Sekolah Dalam Menumbuhkan Minat Baca Peserta Didik Sdn Kuripan Lor 01 Kota Pekalongan." Jurnal IImu Perpustakaan, vol. 7, no. 2, 2018, pp. 71-80, https://ejournal3.undip.ac.id/index.php/jip/article/view/22894.

Kominfo. "Kominfo Ajak Delegasi Ministerial WSIS Forum Kembangkan.” Kominfo.Go.Id, 2021, https://kominfo.go.id/content/detail/34576/siaran-pers-no171hmkominfo052021-tentang-kominfo-ajak-delegasi-ministerial-wsis-forumkembangkan-masyarakat-digital/0/siaran_pers.

Lasa H, and Uminurida Suciati. Kamus Kepustakawanan Indonesia (Edisi Revisi). 4th ed., Calpulis, 2014.

Mustangin, Mustangin. "Peningkatan Minat Baca Dan Kemampuan Berbahasa Inggris Anak Di Rumah Baca Bandung." Jurnal Imiah Pendidikan Dan Pembelajaran, vol. 2, no. 2, 2018, pp. 133-41, doi:10.23887/jipp.v2i2.14464.

Perpusnas RI. Wadahi Pegiat Literasi, Perpusnas Luncurkan Akademi Literasi. 2021, https://www.perpusnas.go.id/newsdetail.php?lang=id\&id=21061606383590Srei4JWd. 
Rodin, Roni. Transisi Masyarakat Indonesia Menuju Masyarakat Informasi 1. 2013, pp. 159-164, http://journal.unair.ac.id/PALIM@transisi-masyarakat-indonesiamenuju-masyarakat-informasi-article-11146-media-86-category-8.html.

Wahyuni, Sri. "Peran Pustakawan Sebagai Agent Of Change Dalam Memberikan Layanan Kepada Pemustaka.” Libraria, vol. 10, no. 2, 2018, pp. 1-9, https://jurnal.arraniry.ac.id/index.php/libria/article/view/4062/2913. 